\title{
HERMENEUTYKA ZMARTWYCHWSTANIA CHRYSTUSA
}

Zmartwychwstanie Jezusa Chrystusa jest dogmatem wiary ze zwyczajnego nauczania Kościoła, zawierającym się w wyznaniu wiary nicejsko-konstantynopolitańskim ${ }^{1}$ : ,,crucifixus etiam pro nobis [...] passus et sepultus est, et resurrexit tertia die secundum Scripturas [...]".

W tej formule można wyróżnić trzy elementy:

a) ścisły związek między męką, śmiercią i zmartwychwstaniem;

b) zmartwychwstanie, które nastąpiło trzeciego dnia;

c) wszystko to stało się według Pisma.

W tradycji biblijnej męka i zmartwychwstanie Jezusa są z sobą związane; tak pouczają najstarsze formuły kerygmatyczne: przepowiadanie apostolskie $(\mathrm{Dz} 3,15)$ i najstarsze wyznanie wiary (1 Kor 15, 3-5). Chrystus ukrzyżowany jest przedmiotem przepowiadania Pawłowego (por. 1 Kor 1, 23; 2, 2; Rz 6, 3. 5. 6.) ${ }^{2}$. Krzyż stał się znakiem zbawienia, choć był szubienicą dla niewolników i złoczyńców: ,crucifixus e ti a m pro nobis" jest oparte niewątpliwie na kultycznej formule wiary z Flp 2, 7: „,factus oboediens usque ad mortem, mortem autem crucis" 3.

Zwróćmy uwagę na powiązanie faktów przy pomocy spójnika ,et” lub poprzez równorzędne zestawienia. Zmartwychwstanie w as pekcie faktograficznym znajduje się na tym samym poziomie co męka i śmierć. Kwalifikator chronologiczny ,,tertia die" nadaje faktowi zmartwychwstania ramy czasowe, umieszczając je na płaszczyźnie zjawisk historycznych. Wreszcie kwalifikator teologiczny ,secundum Scripturas"

1 DS, 150

2 Zob. G. Hierzenberger, Kreuz und Auferstehung, w: A. Grabner - Haider, Die Bibel und unsere Sprache. Konkrete Hermeneutik, Wien-Freiburg-Basel 1970. J. Guillet, Die Mitte der Botschaft: Jesu Tod und Auferstehung, „Internat. kath. Zeit schrift Communio", 2 (1973) 225-238.

3 J. Vogt, Crucifixus etiam pro nobis, "Internat. kath. Zeitschrift Communio", 2 (1973) $186-191$. 
wskazuje na teksty biblijne Starego Testamentu, które sprawdzają się poprzez zaistniałe fakty ${ }^{4}$. Mamy tedy do czynienia $\mathrm{z}$ formułą wiary ${ }^{\text {, }}$ która niewątpliwie jest wzorowana na najstarszej formule chrześcijańskiego credo, umieszczonej przez św. Pawła w 1 Kor $15,3-5{ }^{6}$.

Powstaje pytanie, jak można interpretować $\mathrm{dzisiaj}$ formułę nicejsko-konstantynopolitańską dotyczącą zmartwychwstania Chrystusa, zachowując jej autentyczną wartość. Innymi słowy — jak daleko może pójść hermeneutyka dogmatu zmartwychwstania Chrystusa, ażeby obiektywny sens prawdy nie został zmieniony. Zadaniem niniejszego studium jest danie odpowiedzi na to pytanie, którą dla większej klarowności podzielimy na dwie części. W pierwszej części przedstawimy jedną z prób współczesnej interpretacji prawdy zmartwychwstania Jezusa, interpretacji dokonanej na gruncie katolickim i zaproponowanej do wykorzysta-. nia katechetycznego. Druga część będzie analizą owej interpretacji oraz wskazaniem granic i możliwości nowej interpretacji dogmatu zmartwychwstania.

\section{ZMARTWYCHWSTANIE CHRYSTUSA JAKO INTERPRETACJA}

Ostatnie dziesiątki lat przyniosły rozmaite próby interpretacji zmartwychwstania Chrystusa ?. Od ujęcia apologetycznego autorzy przeszli do egzegezy tekstów biblijnych ${ }^{8} \mathrm{i}$ analizy języka biblijnego opisującego fakt zmartwychwstania ${ }^{9}$. Zaczęto stosować metodę zwaną Formgeschichte,

4 Posługując się pojęciami semiotyki można by mówić o znakach-wydarzeniach. Zob. L. Marin, Sémiotique de la Passion. Topiques et figures (Bibliothèque de Sciencos religieuses), Paris 1971.

Na temat biblijnych formul wiary zob. V. N. Neufeld, The Earliest Christian Confessions (New Testament Tools and Studies, 4) Leiden 1963.

6 Bibliografia na temat tejże formuły jest obszerna, z najważniejszych opracowań należy wymienić: J. Kremer, Das älteste Zeugnis von der Auferstehung Christi. Eine bibeltheologische Studie zur Aussage und Bedeutung von 1 Kor 15, 1-11 (Stuttgarter Bibelstudien, 17), Stuttgart 1967. - K. Lehmann, Auferweckt am dritten Tag nach der Schrift. Früheste Christologie, Bekenntnisbildung und Schriftauslegung im Lichte von 1 Kor 15, 3-5 (Quaestiones disputatae, 38), Freiburg-Basel-Wien 1968. -Zob. także S. Lyonnet, La Risurrezione di Cristo nella Prima Lettera ai Corinti, „L'Osservatore Romano", 24-25 Aprile 1973, 5.

7 Zob. P. de Haes, La résurrection de Jésus dans l'apologétique des cinquante dernières année (Analecta Gregoriana, 59), Romae 1958. - C. ITartini, Il problema storico della Risurrezione negli studi recenti. Lo stato attuale della questione de! problema storico-critico della Risurrezione di Cristo alla luce degli studi e dei metodi esegetici recenti (Analecta Gregoriana, 104), Roma 1959. - P. Grelot, Croire au Christ ressuscité, „Etudes”, 337 (juillet 1972) 119-141.

8 Zob. P. de "Surgy, P. Grelot, M. Carrez, A. George, J. Delorme, X. Léon-Dufour, La Résurrection du Christ et l'exégèse moderne (Lectio divina, 50), Paris 1968.

9 Zob. J. Ponthot, P. Hitz et alii, La Résurrection du Christ: Evénement, mystère, catéchèse, Bruxelles 1967. - X. Léon-Dufour, Résurrection de Jésus et message pascal, Paris 1971. Do tej książki powrócimy jeszcze osobno. - J. Delorme, La Résurrection de Jésus dans le langage du Nouveau Testament, w: Le langage de la foi dans l'Ecriture et le monde actuel (Lectio divina, 72), Paris 1972. 
a później Redaktionsgeschichte, do perykop zmartwychwstania ${ }^{10}$. Pytanie o fakt zostaje zastąpione pytaniem o znaczenie faktu. Stąd też trak-towanie zmartwychwstania nie jako opisu, informacji, lecz jako interpretacji pierwszych chrześcijan ${ }^{11}$. Z drugiej strony pojawiają się rozmaite próby współczesnego odczytania owej pierwotnej interpretacji, czyli ,iriterpretacje interpretacji".

\section{Katolicka interpretacja demitologizująca}

Klasycznym przykładem interpretacji dogmatu zmartwychwstania. Chrystusa może być tzw. „katechetyczny eksperyment” w Holandii. Chodzi tutaj o podręcznik do nauki religii dla młodzieży szkół średnich (Sekundarstufe II), jaki został opracowany przez zespół katechetyczny w uniwersytecie w Nijmegen i wprowadzony ad experimentum w dwóch diecezjach holenderskich, mianowicie 's-Hertogenbosch i Breda. Podręcznik ów, nazywany w skrócie OMO-Kursus(OMO = Ons Middelbaar Onderwijs), otrzymał imprimatur biskupów tychże diecezji w formie przedmowy ${ }^{12}$. Ujęcie prawd dogmatycznych w OMO-Kursus spowodowało nie tylko interwencję Stolicy Apostolskiej, lecz także krytykę ze strony teologów, a w tym również wyraźną opozycję w samej Holandii ${ }^{13}$. Mamy zatem do czynienia z bardzo kontrowersyjną próbą przedstawienia dogmatów ze strony katolickiej, próbę wychodzącą już poza warsztat teologów, a zastosowaną do praktyki katechetycznej. Ze względu więc na sposób przedstawienia zajmiemy się tutaj omówieniem tylko interpretacji danych biblijnych o zmartwychwstaniu Jezusa ${ }^{11}$.

1.1 Zakładając rzeczywistość faktu śmierci Jezusa OMO-Kursus nie stawia na tej samej linii wydarzeń innego faktu - zmartwychwstania.

10 Por. P. Benoit, Passion et Résurrection du Seigneur (Lire la Bible, 6), Paris 1966. - L. Schenke, Le Tombeau vide et l'annonce de la Résurrection (Lectio divina, 59), Paris 1970. - X. Léon-Dufour, dz. cyt.

11 Próbą ze strony katolickiej jest książka X. Léon-Dufoura, dz. cyt. Autor tak określa cel swojej pracy: „Or, ce n'est pas l'événement passé que nous interprétons, mais bien le langage dans lequel nous est "présenté " l'événement de jadis." (tamże, $18 \mathrm{n})$.

12 Opieram się na relacji pt. Katechetisches Experiment in Holland geschcitert? umieszczonej W „Herder-Korrespondenz" 26 (Dezember 1972) 579-581.

Podręcznik OMO-Kursus dzieli się na cztery części: I. Religie ludzkości, II. Omówienie pism Starego Testamentu, III. Omówienie pism Nowego Testamentu, IV. Wiara i światopogląd. Przedmowę napisał biskup diecezji s'Hertogenbosch, J. Bluyssen, także w imieniu biskupa z Bredy, J. Ernsta, z życzeniem pomyślnych wyników.

13 Trzeba tutaj wymienić kilka listów kardynałów prefektów rzymskich kongregacji, F. Šepera i J. Wrighta co biskupów s'Hertogenbosch i Bredy, zakazujących rozpowszechniania metody ONO-Kursus; krytyczny artykul J. Galot w „Civiltà Cattolica" z maja 1972; krytykę ze strony H. van Dijka w czasopiśmie holenderskim „Confrontatie" (marzec 1971). Doszlo także do faktów dezobediencji, kiedy to zespół OMO-Kursus odrzucił prośbę biskuców Bluyssena i Ernsta o wycofanie części III i IV podręcznika.

${ }_{14} \mathrm{Cz}$. III. Przedstawienic Zmartwychwstania, ss. XVII--3. 
Wprost wyraźnie neguje dedukcję zmartwychwstania z faktu pus tego grobu: „pusty grób” wcale nie jest korelatem stwierdzenia „pochowany w grobie”, ,,pogrzebany”. Niemniej jednak wszystkie wypowiedzi 'biblijne wskazują, że grób nie był końcem Chrystusa, np. stwierdzenie, że „Bóg wybawił Go od śmierci”. Drogą więc, na której pierwsi chrześcijanie doszli do przeświadczenia, że grób nie był końcem Chrystusa, było nie doświadczenie faktu, przeżycie kontaktu ze Zmartwychwstałym, lecz lektura Pisma świętego. Jako wyjaśnienie tego tajemniczego przeświadczenia spotykamy w pierwszych wyznaniach wiary zwrot „według Pisma” (por. 1 Kor 15, 3-5). Pierwsi chrześcijanie nie interesowali się sposobem zmartwychwstania, wyrazili jednak w języku swoich czasów aż do przesady to, co zmartwychwstanie wyraża. Zmartwychwstanie zatem jest jak gdyby konstrukcją językową, poza którą ukrywa się prawda, iż Jezus przez zmartwychwstanie zaczął spełniać zupełnie nową rolę jako Mesjasz, Pan, Syn Boży. Wyrażenia takie jak: „,siedzi po prawicy Ojca”, ,,jest ponad Aniołów wywyższony”, „Sędzia żywych i umarłych”, ,,jest naszym pośrednikiem”, „ochrania nas przed nadchodzącym gniewem” wskazują na naczelną rolę Chrystusa jako centrum dziejów świata i ludzkości. I to znaczy więcej niż stawiane pytania o fakty ${ }^{15}$.

1.2 OMO-Kursus neguje wartość faktograficzną wyrażenia „trzeciego dnia”. Wszystko wskazuje na to, że chodzi tu o tzw. „dowód z Pisma św.", zaczerpnięty przez pierwszych chrześcijan z proroka Ozeasza $(6,2){ }^{16}$.

1.3 Problem chrystofanii ustawia OMO-Kursus na płaszczyźnie językowej. Mianowicie wyrażenie ,ukazał się” nie musi być identyczne z wyrażeniem „widzieliśmy go". To pierwsze wyrażenie jest pojmowane w sensie nie stwierdzenia faktu zobaczenia Zmartwychwstałego, lecz w znaczeniu struktury zwrotu językowego, znanego w Starym Testamencie, a mó-

15 ,Wenn auch die ersten Christen nich über das »leere Grab« sprechen, so verkünden sie doch, dass Jesus »begraben " oder »ins Grab gelegt w wurde. Hiermit wollen sie sagen, dass er wirklich gestorben ist. Aber aus all ihren Gesprächen und Äusserungen darf man schliessen, dass sie darin nicht das Ende sahen. Felsenfast folgt auf die Verkündigung von Tod und Begräbnis die andere: "Aber Gott erweckte ihn von den Toten." Als Erklärung und Auslegung dieser mysteriösen Behauptung wird ein Schriftbeweis ("gemäss der Schrift«) angeführt..."

Es scheint, dass die ersten Christen besonders durch die Lektüre der Schrift von dem Bewusstsein überwältigt wurden, dass die Sache mit Jesus nicht zu Ende sei. Das Wie der Auferstehung interessiert sie offensichtlich nicht, sie geben aber in der Sprache ihrer Zeit bis zum Úberfluss wieder, was Auferstehung bedeutet. Durch die Auferstehung beginnt Jesus eine völlig neue Rolle zu spielen [...]

Das bedeutet in unserer Sprache, dass Jesus der Mittelpunkt und der Garant des Weltgeschehens und der Menschheitsgeschichte geworden ist. Das ist doch mehr als die Fragen, die wie noch immer stellen, ob es nämlich keine »Fakten " gibt, auf die man sich berufen kann.” (cyt. za „Herden-Korrespondenz” — w dalszym ciągu używać będziemy skrótu HK).

16 ,Aber haben wir keinen festen Halt am »dritten Tag «? Alles weist darauf hin, dass es sich auch hier um einen »Schriftbeweis « und nicht um ein Faktum handelt. Damit verwiesen die ersten Christen auf einen Text aus dem propheten Hosea: "Er wird uns beleben nach zwei Tagen, und am dritten Tage uns aufrichten, dass wir vor ihm leben« $(6,2)$." (cyt. za HK). 
wiącego o tym, że Zmartwychwstały stał się przedmiotem sądu wartościu-jącego, to znaczy dał się poznać, kim jest i co to oznacza. A że w Nowym Testamencie jest mowa o świadkach zmartwychwstania, OMO-Kursus zacieśnia pojęcie świadka do dawania, czyli głoszenia świadectwa o Zmartwychwstałym, wykluczając arbitralnie możliwość istnienia świadka naocznego Zmartwychwstałego ${ }^{17}$.

$1.4 \mathrm{~W}$ konkluzji OMO-Kursus kwalifikuje zmartwychwstanie jako pytanie wiary, a nie fakt, względnie zespół faktów, który może być stwierdzony. Jedynie co może być przez nas stwierdzone, to fakt, że mimo „fiaska Chrystusa” w oczach Żydów i Greków pierwsi chrześcijanie nie mogli nie głosić na cały świat, iż Jezus zmartwychwstał, c) stało się dziwnie zaraźliwym ${ }^{18}$.

Z powyższego przeglądu wynika, że OMO-Kursus atakuje wszystkie elementy dogmatycznej prawdy o zmartwychwstaniu. Metoda, która została przyjęta przez autorów podręcznika, może być nazwana metodą a n a liz y ling w ist y c z n e j: jest to więc zanegowanie faktu stwierdzalnego na rzecz struktury języka, odrzucenie możliwości poznania na drodze doświadczenia faktu, a przyjęcie typu refleksji treści biblijnych ${ }^{19}$; arbitralne zacieśnienie danych skrypturystycznych i odrzucenie całego kontekstu życiowego (Sitz im Leben) tychże danych. Metoda ta sięga do klasycznych wzorów tzw. demitologizacji, proponowanej przez R. Bultmanna ${ }^{20}$. Nic przeto dziwnego, że takie ujęcie interpretacyjne zmar-

17 ,Und die Erscheinungen? Wenn auch in der folgenden Lektion darauf näher eingegangen wird, können wir jetzt schon sagen, dass der Ausdruck »Er ist erschienen " nicht identisch sein muss mit der Aussage "Wir haben ihn gesehen «. Wie im Alten Testament bedeutet diese Ausdruckweise, dass der auferstandene Herr sich offenbart, d. h., er lässt einsichtig erkennen, wer er ist und was er bedeutet. Aber warum sagen dann die ersten Christen immer, dass sie "Zeugen "sind? Wovon sind sie denn Zeugen? Zeugen bedeutet im Neuen Testament etwas anderes, als wir auf den ersten Blick darunter verstehen. Es wird beispielweise auch vom Heiligen Geist gesagt, dass er die Auferstehung bezeugt. Daraus erhallt, dass wir es hier nicht $\mathrm{zu}$ tun haben mit Augenzeugen, die eventuell im Zeugenstand vor Gericht ein Faktenzeugnis ablegen können. Im Neuen Testament bedeutet „bezeugen” etwas ausposaunen (das griechische Wort kerygma bedeutet die Mitteilung eines Heroldes), über etwas seinen Mund nicht halten können, oder etwas frömmer: verkündigen, predigen." (cyt. za HK).

${ }_{18}$,Wir kommen nicht daran vorbei: Die Auferstehung ist nicht an erster Stelle eine Frage von "Fakten«, die konstatierbar sind, sondern eine Frage des Glaubens. Die für uns konstatierbaren Fakten sind - trotz der Tatsache, dass Jesus in den Augen der Juden und Griechen gescheitert war -, dass die ersten Christen ihren Mund nicht halten konnten und bekannten: Er ist auferstanden. Diese weltbedeutende Erkenntnis posaunen sie aus, und sie wirkt offensichtlich ansteckend." (cyt za HK).

19 Widać tu wpływ hermeneutyki neopozytywistycznej. Zob. D. Antiseri, Filosofia analitica e semantica del linguaggio religioso (Giornale di Teologia, 31). Brescia ${ }^{2} 1970$. Można tutaj również mówić o wpływie jednego z czołowych przedstawicieli teologii radykalnej (zw. „teologią śmierci Boga"), jakim jest P. van Buren, który w książce The Secular Meaning of the Gospel, New York 1963, pisze o doświadczeniu subiektywnym Piotra i innych w czasie Paschy.

20 H. van Dijk w "Confrontatie" (marzec 1971) 25 nn, nazywa autorów kursu „Entmythologiesierungskoryphäen wie Baur, Bultmann und Marxsen”. (cyt. za HK). 
twychwstania zostało nazwane destruktywnym ${ }^{21}$. Możemy bez przesady stwierdzić, że doczekaliśmy się katolickiego wydania demitologizacji typu bultmannowskiego z poprawkami wniesionymi przez tzw. „nową hermeneutykę". Wydaje się przeto słusznym, ażeby przed przystąpieniem do przedstawienia argumentów za faktograficznym potraktowaniem zmartwychwstania, poświęcić nieco uwagi historycznym uwarunkowaniom procesu kształtowania się koncepcji demitologizującej fakt zmartwychwstania Jezusa.

\section{Rodowód katolickiej hermeneutyki demitologizującej}

Dla R. Bultmanna zmartwychwstanie Jezusa jest refleksem Jego śmierci krzyżowej. Wiara $w$ zmartwychwstanie nie jest niczym innym jak tylko wiarą w krzyż jako zbawcze wydarzenie (Heilsgeschehen), jako krzyż Chrystusa ${ }^{22}$. Jakie podstawy ma owa wiara? Oddajmy głos samemu Bultmannowi. „Jedyną postawą naszej wiary w zbawczą wartość krzyża, czyli wiary w zmartwychwstanie, jest słowo przepowiadania. W tym oto słowie, i tylko w nim, Chrystus ukrzyżowany i zmartwychwstały nas spotyka. I właśnie ta wiara $\mathrm{w}$ to słowo jest prawdziwą wiarą paschalną" 23. Stanowisko Bultmanna w tej kwestii jest oczywistą konsekwencją dwóch jego naczelnych zasad hermeneutycznych: demitologizacji i interpretacji egzystencjalnej ewangelii. Stąd zmartwychwstanie jest symbolem, a nie faktem, z n a c z e ni e paschalne zajmuje miejsce faktu, a wi a r a paschalna zastępuje wydarzenie historyczne. Słusznie zauważono, że Bultmann w swojej koncepcji demitologizacji jest scjentystą i antyscjentystą zarazem: człowiek wychowany $\mathrm{w} \cdot$ wiedzy współczesnej nie może - według teologa marburskiego - godzić się na zmartwychwstanie jako na „ożywienie ciała”, a z drugiej strony tenże sam człowiek tylko w egzystencjalnym akcie jest zdolny do wiary, odrzucając całą obiektywną rzeczywistość ${ }^{24}$. Wydaje się, że autorzy OMO-Kursus ulegli wplywowi Bultmanna przynajmniej w tym, iż ważne jest znaczenie (Dass), a nie fakt (Was lub Wie).

Pozycję niemniej ahistoryczną odnośnie zmartwychwstania Chrystusa zajęli koryfeusze tzw. „nowej hermeneutyki”, jakimi są E. Fuchs i G. Ebeling, aczkolwiek przyjmują oni razem z całą szkołą pobultman-

21 W liście kard. Šepera (cyt. za HK).

22 R. Bultmann, Neues Testament und Mythologie (1941), w: H. W. Bartsch, Kerygma und Mythos, Hamburg 1948, I 44-46.

23 R. Bultmann, Das Verhältnis der urchristlichen Botschaft zum historischen Jesus, Heidelberg ${ }^{3} 1966,27$. - Por. R. Marlé, Bultmann et l'interprétation du Nouveau Testament (Théologie, 33), Paris 21966, 158-170. - W. Knevels, Dio è realtà, Brescia 1966, 111-127 [oryg. Die Wirklichkeit Gottes, Stuttgart 1964].

24 Zob. P. Valori, Problemi filosofici della ermeneutica, w: Esegesi ed ermeneutica. Atti della XXI Settimana Biblica, Brescia 1972, 30. 
nowską, poczynając od E. Käsemanna, zasadę Jezusa historycznego ${ }^{25}$. Zmartwychwstanie nie jest faktem historycznym, obiektywnym, należy do sfery mitycznej. Demitologizacja wprowadzona przez ,nową hermeneutykę" polega - podobnie jak u Bultmanna - na wierze w skandal śmierci krzyżowej Jezusa. Wiara paschalna to wyznanie, że Jezus był istotnie Słowem, ponieważ umarł na krzyżu. Hermeneutyka zmartwychwstania według Fuchsa polega na tym, by samemu, niejako stanąwszy pod krzyżem, stwierdzić, co on istotnie oznacza ${ }^{26}$. Pozwala to nam na przezwyciężenie naszych słabości, ponieważ słowo-wydarzenie przetrwało śmierć. Fakty po zmartwychwstaniu nie liczą się ze względu na swój obiektywizm, lecz tylko dlatego, że zawierają się w języku o zwyciçstwie krzyża. W tym sensie należy patrzeć na ukazywania się Zmartwychwstałego: nie chodzi o to, że są wydarzeniami obiektywnymi, które podbudowują naszą wiarę, lecz są one ważne ze względu na niejako kontynuację nauczania Chrystusa ${ }^{27}$. Zmartwychwstanie tworzy słowa-wydarzenia (Sprachereignis lub Wortgeschehen), wywołuje wiarę ,lingwistyczną”. Owa wiara , lingwistyczna” jest powtórzeniem tej wiary w Boga, którą wlał nam Jezus w swoim nauczaniu. Ponieważ to nauczanie przetrwało na krzyżu, jest wydarzeniem, które ,nowa hermeneutyka" utożsamia z misterium paschalnym.

Jak widać z tego, u przedstawicieli ,nowej hermeneutyki” stwierdzić można niechęć, wprost wrogość, względem faktów obiektywnych, natomiast predylekcję do tzw. faktów języka, czyli języka-który-tworzy-wydarzenia. Niewątpliwie można odczuć wpływ ,nowej hermeneutyki” na koncepcję autorów OMO-Kursus zwłaszcza wszędzie tam, gdzie chodzi o relację: język - wydarzenie.

Jeszcze jeden wpływ wydaje się być oczywistym. Chodzi tu o poglądy egzegety protestanckiego W. Marxena ${ }^{28}$, które mogą uchodzić za klasyczny przykład swoistej dychotomii w stosowaniu metody historycznej. Z jednej strony bowiem uczniowie Chrystusa dostąpili widzenia Ukrzyżowanego, byli prawdziwymi świadkami chrystofanii. Na podstawie widzeń doszli do stwierdzenia, że Chrystus zmartwychwstał, i o faktyczności tego byli jak najmocniej przekonani. Z drugiej jednak strony my już nie możemy dojść do tego przeświadczenia, nie dlatego, że nie jesteśmy, jak oni, naocznymi świadkami chrystofanii, lecz dlatego, że

25 Zob. P. Grech, La nuova ermeneutica: Fuchs ed Ebeling, w: tamże, 71-90. G. Ebeling stawia problem pustego grobu i chrystofanii, które nie są podstawą naszej wiary w zmartwychwstanie, gdyż chodzi tutaj o sam akt wiary niezależnie od dowodów obiektywnych. Zob. tegoż Wort und Glaube, Tübingen ${ }^{3} 1967,312$ n.

26 Zob. E. Fuchs, Hermeneutik, Bad Cannstatt ${ }^{3} 1963,189,258$. Tenże, Marburger Hermeneutik (Hermeneutische Untersuchungen zur Theologie, 9), Tübingen 1968, 218.

27 Zob. G. Ebeling, Wort und Glaube, 314.

28 Zob. jego Die Auferstehung Jesu als historisches und als theologisches Problem, Gütersloh 21965. Tenże, Die Auferstehung Jesu von Nazareth, Gütersloh 1968. 
jest nam dostępna tylko suma refleksji, która doprowadziła uczniów do prawdy o zdarzeniu zmartwychwstania ${ }^{29}$. To, do czego dzisiaj możemy dojść, to nie fakty przekazane nam przez wiarogodnych świadków, lecz treść interpretacyjna wydarzenia zmartwychwstania ${ }^{30}$. Stawia więc Marxsen niejako barierę między widzeniami Apostołów a przedmiotem tychże widzeń, czyli Zmartwychwstałym, barierę dla nas nieprzeniknioną i nieprzekraczalną.

Nietrudno pozycję Marxsena odnaleźć w artykule B. van Iersela pod znamiennym tytułem: La résurrection de Jésus: information ou interprétation ${ }^{31}$. Opisy ewangeliczne są wyrazem samozrozumienia pierwotnej społeczności chrześcijańskiej. Nie mamy więc informacji, jest tylko interpretacja. Nawet jeśli za treścią interpretacyjną kryją się jakieś fakty, to nie możemy nic pewnego powiedzieć ani odnośnie natury tychże faktów, ani też o kryteriach ich sprawdzalności.

Zatrzymaliśmy się dłużej nad analizą współczesnych poglądów egzegetycznych, które przyjąwszy pozytywistyczną koncepcję historii ${ }^{32}$ wprowadzają rozdział faktu od jego interpretacji, dochodząc w ten sposób do negacji samego faktu, w naszym konkretnym przypadku - faktu zmartwychwstania Jezusa. Jest chyba rzeczą konieczną uprzytomnić sobie genealogię interpretacji demitologizującej, zaproponowanej przez egzegetów katolickich - jest to prosta droga od Bultmanna, poprzez „,nową hermeneutykę" i Marxsena ${ }^{33}$.

29 W. Marxsen, Die Auferstehung Jesu als... Problem, 19.

30 ,ein frühes Interpretament des Auferstehungsereignisses”. Die Auferstehung Jesu von Nazareth, 23.

31 „Concilium”, nr 60 (1970) 51-62 (wersja francuska). Van Iersel, wykładowca Nowego Testamentu w uniwersytecie w Nijmegen, musiał w jakiś sposób oddziałać na zespół redagujący OMO-Kursus.

32 Zob. L'histoire et l'historien. Praca zbiorowa: Recherches et débats du Centre Catholique des Intellectuels Français, cahier 47, Paris 1964. - I. Berten, Histoire, révélation et foi. Dialogue avec W. Pannenberg, Bruxelles 1969, 36-45; 68-85. $\mathrm{X}$. Léon-Dufour, Résurrection de Jésus et message pascal, 252-257. - P. Grelot, L'historien devant la Résurrection du Christ, „Revue d'Histoire de la Spiritualité”, 1972, nr 2. - B. Rigaux, Dieu l'a ressuscité, Gembloux 1973, 289-297.

33 Przykładem tego, że ta droga prowadzi do nikąd, jest Dossier sur la résurrection. Lettre, "Temps Présent”, nr 163-164, Paris (mars-avril 1972), zawierające wyniki czteroletnich poszukiwań na temat zmartwychwstania Chrystusa ze strony grupy nie-specjalistów przy pomocy specjalistów. W tym biuletynie buńczuczność wypowiedzi walczy o lepsze z brakiem logiki. Oto próbki wypowiedzi: E. Floris stosując do Ewangelii hermeneutykę typu ,scienza nuova” Giambattisty Vico kwalifikuje opowiadanie $€ \mathrm{k} \mathrm{24}$, 36-39 jako „langage symbolique épique” (s. 21). J. Cardonnel interpretuje 1 Kor $15 \mathrm{w}$ sensie: ,ce n'est pas d'un résurrection individuelle du Christ que l'on fait dériver la résurrection des hommes, mais c'est la résurrection historique des hommes qui vérifie la résurrection du Christ." (s. 27). M. Oraison bije rekord paradoksu w wyznaniu: ,Je crois à ma résurrection parce que j'ai l'impression que je ne peux pas être détruit” (s. 30), a także pisząc: ,je croirais peut-être encore davantage à la résurrection du Christ si l'on avait retrouvé ses ossements" (s. 31). 


\section{ZMARTWYCHWSTANIE CHRYSTUSA JAKO WYDARZENIE}

Trzeba nam teraz przejść do pozytywnego wykładu głównych tez, na których można oprzeć obiektywne wydarzenie zmartwychwstania Jezusa. Nie będzie to przegląd analityczny; naszym zdaniem jest sformułowanie podstawowych tez hermeneutycznych, które pozwoliłyby nam ując zmartwychwstanie Chrystusa nie w ramach treści interpretacyjnych, lecz jako obiektywne wydarzenie, względnie zespół wydarzeń.

\section{Fakt pustego grobu a antropologia hebrajska}

Musimy rozpocząć od stwierdzenia faktu pustego grobu, gdyż jego zanegowanie prowadzi do dalszych negacji.

Błędem niektórych egzegetów jest twierdzenie, że opis wizyty niewiast $u$ grobu powstał $z$ kultu lub $z$ racji apologetycznych ${ }^{34}$. Twierdzenic takie mogło się zrodzić pod wpływem zafascynowania metodą ,, historii form" (Formgeschichtliche Methode) i chęcią wytłumaczenia genezy poszczególnych perykop w odpowiednim kontekście życiowym (Sitz im Leben) liturgii i katechezy pierwotnego Kościoła. Natomiast twierdzenie takie nie uwzględnia należycie danych antropologii hebrajskiej, według której cielesność należy do natury człowieka ${ }^{35}$. Jeżeli więc w Jerozolimie była mowa o zmartwychwstaniu Jezusa, to dlatego, że każdy mógł zweryfikować pusty grób, w którym uprzednio Jezus był pochowany. Na ten aspekt antropologii żydowskiej zwrócił ostatnio uwagę K. Schubert ${ }^{36}$. A że jest to moment bardzo istotny, świadczy dawniejsza hipoteza H. Grassa, że opowiadanie o pustym grobie powstało jako treść inter-

34 Zob. G. Schille, Das Leiden des Herrn. Die evangelische Passionstradition und ihr Sitz im Leben, „Zeitschrift für Theologie und Kirche”, 52 (1955) 161-205. J. Delorme, Résurrection et tombeau de Jésus, w: La résurrection du Christ et exégèse moderne (Lectio divina, 50), Paris 1969, 105-151. - L. Schenke, Auferstehungsverkündigung und leeres Grab. Eine traditionsgeschichtliche Untersuchung von Mk 16, 1-8 (Stuttgarter Bibelstudien, 33), Stuttgart 1969. [Tłum. franc.: Le tombeau vide et l'annonce de la Résurrection (Lectio divina, 59), Paris 1970]. - J. Broer, Die Urgemeinde und das Grab Jesu. Eine Analyse der Grablegungsgeschichte im Neuen Testament (Studien zum A. und NT, 31), München 1972.

35 Zob. A. Gelin, L’homme selon la Bible, Paris 1968. [Tłum. polskie: Pismo świete o człowieku (Editions du dialogue, 18), Paris 1971]. - W. Mork, The Biblical Meaning of Man, Milwaukee. [Tłum. włoskie: Linee di antropologia biblica (Biblia e Oriente, 2), Fossano 1971]. - G. Stemberger, Der Leib der Auferstehung. Studien zur Anthropologie und Eschatologie des palästinischen Judentums im neutestamentlichen Zeitalter (c. 170 v. Chr. - 100 n. Chr.), (Analecta biblica, 56), Rom 1972.

36 K. Schubert, Jesus im Lichte der Religionsgeschichte des Judentums, referat wygłoszony na kursie teologicznym w Salzburgu, w lecie 1972 r. Podaję za: O. Schatz. Auf der Suche nach dem wirklichen Jesus. Zur Thematik der diesjährigen Salzburger Hochschulwochen, "Herder-Korrespondenz”, 26 (Oktober 1972) 486-488. - Por. $\mathrm{K}$. Schubert, Die Entwicklung der Auferstehungslehre von der nachexilischen bis zur frührabbinischen Zeit, „Biblische Zeitschrift”, 6 (1962) 177-214. - Zob. również J. F. A. Sawyer, Hebrew Words for the Resurrection of the Dead, ,Vetus Testamentum", 23 (1973) 218-234. 
pretacyjna dorobiona do wymogów antropologii hebrajskiej, która żądała, ażeby przy mówieniu o fakcie zmartwychwstania nie można było udowodnić obecności zwłok ${ }^{37}$. Dlatego też wielu egzegetów katolickich -.. że wyliczymy tylko P. Benoit, A. Vögtle, X. Léon-Dufour - a nawet protestanckich, jak H. von Campenhausen, widzą w perykopach o niewiastach u grobu sprawozdanie z faktu zaistniałego ${ }^{38}$. Zatem opowiadanie o pustym grobie możemy zaliczyć do tej samej grupy faktów co pogrzeb Chrystusa, co do historyczności którego nikt dzisiaj nie ma wątpliwości. Niewiasty przybyły do grobu, aby stwierdzić, że jest pusty to jest istota opowiadania. Wszystko inne należy już do pracy redakcyjnej (Redaktionsgeschichte). Nie ma tedy potrzeby uciekania się do interpretacji o czczeniu pamięci zmarłego przez przychodzenie do grobu, jak chce teoria kultyczna, lub o świadectwie ze strony niewiast, co zresztą byłoby dziwne w mentalności hebrajskiej (kobieta żaden świadek!) — a więc nıe cel apologetyczny. Istotnym jest tutaj fakt - pusty grób, fakt, który mógł każdy sprawdzić, tak jak sprawdziły go kobiety, a potem Apostołowie, a przez ich opis wiarogodny jest i nam dostępny.

Zwróćmy jeszcze uwagę na jeden rys mentalności hebrajskiej odnośnie pamięci o zmarłych. U Żydów spotykamy się ze zwyczajem powtórnego pogrzebu, polegającego na tym, że kości zmarłego zbierano z grobu, namaszczano je i składano w tzw. ossuariach ${ }^{39}$. Otóż nigdy i nigdzie w tradycji chrześcijańskiej nie spotykamy się ze śladami kultu ossuarium Chrystusa, a w każdym razie na taki ślad nie powoływali się nigdy przeciwnicy zmartwychwstania Jezusa. Trudno byłoby przypuścić, żeby nikt z rodziny, z uczniów czy z przyjaciół Jezusa ukrzyżowanego nie pomyślał o takim powtórnym pogrzebie jako dowodzie czci pośmiertnej dla Mistrza. Byłoby to wbrew świętym zwyczajom sepulkralnym i przyjętym kanonom myślenia żydowskiego. Widocznie zaistniał fakt, który uniemożliwił uczynienie powtórnego pogrzebu kości Chrystusa.

37 H. Grass, Ostergeschehen und Osterberichte, Göttingen 1956 ( $\left.{ }^{4} 1970\right)$. - Zob. $\mathrm{X}$. Léon-Dufour, Résurrection de Jésus, 267-271.

38 Zob. X. Léon-Dufour, dz. cyt., 160-162. Ten autor różni się nieco od Benoit i Vögtlego $\mathrm{w}$ rekonstrukcji tradycji istniejących $\mathrm{w}$ perykopie o niewiastach u grobu. Wyróżnia on bowiem trzy stadia: 1) interpretacja wydarzenia w kierunku podkreślenia zwycięstwa Chrystusa nad śmiercią; 2) tradycja związana z uczniami (por. rolę Piotra u Mk); 3) modyfikacja tradycji u Ek. Rekonstrukcja - naszym zdaniem dość arbitralna.

39 Zob. E. M. Meyers, Jewish Ossuaries: Reburial and Rebirth. Secondary Burials in their Ancient Near Eastern Setting (Biblica et Orientalia, 24), Rome 1971. J. Chmiel, Znaczenie odkrycia ossuarium człowieka ukrzyżowanego dla egzegezy Męki Pańskiej, „Ruch Bibl. i Lit.”, 25 (1972) 229-234. 
2. Chrześcijańska interpretacja Starego Testamentu a doświadczenie nowego faktu

W interpretacji OMO-Kursus musi nas uderzyć twierdzenie, że pierwsi chrześcijanie nie na drodze doświadczenia faktu, lecz poprzez lekturę Pisma św. doszli do przeświadczenia o zmartwychwstaniu Pana. Jako uzasadnienie tego twierdzenia podają występowanie zwrotu ,według Pisma" w najstarszym wyznaniu wiary paschalnej (1 Kor 15, 3-5).

Występuje tutaj pomieszanie kilku spraw. Prawdą jest, że Stary Testament proroczo zapowiada i rozmaitymi obrazami typicznymi oznacza przyjście Chrystusa, Odkupiciela wszystkich, oraz Królestwa mesjańskiego ${ }^{40}$. Analogia, jaka istnieje między faktami historii zbawienia, dokonanymi w Nowym Testamencie, a między ich zapowiedzią w Starym, analogia, która jest podstawą typologii, musi się oprzeć na faktach spełnionych, a nie wymyślonych i intencjonalnie zaistniałych ${ }^{41}$. Pierwsi chrześcijanie nie mogli dojść do przeświadczenia o zmartwychwstaniu Jezusa na drodze refleksji nad tekstami starotestamentalnymi, ponieważ teksty owe nic nie mówią o zmartwychwstaniu Mesjasza. Stary Testament zna pojęcie zmartwychwstania jako wydarzenia uniwersalnego i eschatologicznego. Nigdy natomiast nie mówi o zmartwychwstaniu j edneg o ezłowieka ani o zmartwychwstaniu Mesjasza 42. Nie mogli zatem pierwsi chrześcijanie utworzyć opowiadania o zmartwychwstałym Jezusie, którego uważali za Mesjasza, gdyż to nie mieściło się w systemie ich myślenia; rie mogło to być ,według Pisma”, gdyż Pismo nie zawiera tego. Opowieść o Zmartwychwstałym byłaby niemożliwa, jeśliby się z Nim nie spotkali rzeczywiście po Jego śmierci. Dopiero weryfikacja faktu z zapowiedziami biblijnymi doprowadziła ich do stwierdzenia ,według Pisma".

40 Zob. Dei Verbum, 15.

${ }_{41}$ "Avec le Christ, le Salut promis entre en effet dans le champ de l'expérience humaine. Il n'est plus une réalité future évoquée symboliquement à partir de réalité transcendante évoquée symboliquement à partir de réalités sensibles. Il est un fait d'histoire." P. Grelot, Sens chrétien de l'Ancien Testament, Paris 1962, 398. - Zob. także studia w pracy zbiorowej: Il Messianismo, Atti della XVIII Settimana Biblica, Brescia 1966.

${ }^{42}$,Le judaisme tardif connaît une espérance en la résurrection des morts. La diversité des assertions prouve que la doctrine ne peut être regardée comme centrale dans la pensée religieuse au temps de Jésus. Il n'est pas possible de déterminer l'aire ni la densité des opinions conservées dans la littérature des deux derniers siècles et dans les écrits rabbiniques les plus reculés. La résurrection reste un objet d' hésitation, de spéculation, d'imagerie apocalyptique. [...] Clarté et certitude ne sont venues en ce domaine que par la révélation chrétienne." B. Rigaux, Dieu l'a ressuscité, Gembloux 1973, 15. - Zob. także A.-M. Dubarle, L'attente d'une immortalité dans l'Ancien Testament et le Judaïsme, „Concilium”, nr 60 (1970) 33-42, jak również autorów cytowanych wyżej w przypisie 36. 
W interpretacji zmartwychwstania musimy uwzględnić historyczne fundamentum in re - inaczej grozi nam popadnięcie w jakąś nową mitologię lub gnozę ${ }^{43}$.

Stwierdzenie „według Pisma” odnosi się w formule paulińskiej w 1 Kor 15, 3-5 do dwóch faktów - do śmierci zbawczej Chrystusa i do Jego zmartwychwstania ,trzeciego dnia”. Wyrażenie „trzeciego dnia” jest określeniem historycznym ${ }^{44}$; nie może być wydedukowane $\mathrm{z}$ tekstu $\mathrm{Oz} 6,2$, gdzie ma znaczenie raczej idiomatyczne ${ }^{45}$, aczkolwiek jest widoczny wpływ literacki formuły Ozeasza na wyznanie wiary w 1 Kor ${ }^{46}$.

Podobnie rzecz się ma, jeśli chodzi o ukazywania się Zmartwychwstałego, czyli chrystofanie, których dość długą serię wylicza św. Paweł, kończąc na ostatniej, przez siebie przeżytej, chrystofanii pod Damaszkiem (1 Kor 15, 8). Natomiast sposób przedstawiania tych chrystofanii przez ewangelistów został podyktowany przez dwa różne ujęcia antropologiczne, wynikające $z$ sytuacji pierwotnego Kościoła judeochrześcijańskiego i hellenochrześcijańskiego. Tak więc idea „,cielesności” zmartwychwstania jest zrozumiała w tradycji judeopalestyńskiej i mogła zostać apologetycznie wykorzystana w warunkach katechezy Kościoła judeochrześcijańskiego (perykopy o dotykaniu Chrystusa i o okazywaniu śladów męki) ${ }^{47}$. Zaś zagorzałych ,spirytualistów” kręgu judeohellenistycznego przekonywała perykopa o Zmartwychwstałym „perypatetyku” dzielącym rozmowę i stół $\mathrm{z}$ uczniami ${ }^{48}$. I dlatego to mogło być argumentacją w pracy misyjnej Kościoła hellenochrześcijańskiego. W każdym razie owe rozmaite typy argumentacji antropologicznej wskazują na obiektywny fakt: Jezus był widziany, ukazywał się, naoczni świadkowie stwierdzili tożsamość Jezusa przed i po śmierci ${ }^{49}$.

\section{Konieczność hermeneutyki wydarzenia}

Analizując interpretację zmartwychwstania Jezusa zastosowaną w podręczniku holenderskim użyliśmy argumentacji typu antro-

43 Zwraca na to uwagę $\mathrm{K}$. Schubert w cyt. wyżej konferencji - zob. przypis 36 .

44 Podkreśla to J. Schmitt, Le kérygme et l'histoire de Jésus, w: Où en sont les études bibliques? Les grands problèmes actuels de l'exégèse, pod red. J.-J. Webera i J. Schmitta, Paris 1968, $229 \mathrm{n}$.

${ }_{45}$ J. Wijngaards, Death and Resurrection in Covenantal Context (Hos 6, 2), ,Vetus Testamentum", 17 (1967) 226-239. - J. Chmiel, Problemy struktury literackiej Ozeasza 6, 1-6. Przyczynek do teologii prorockiej, „Analecta Cracoviensia”, 3 (1971) 183-199.

${ }_{46}$ Por. J. Dupont, Ressuscité 'le troisième jour', „Biblica”, 40 (1959) 742-761. Zob. obszerną bibliografię na ten temat w: K. Lehmann, Auferweckt, 360-363, wraz z uzupełnieniami najnowszych pozycji w: B. Rigaux, Dieu l'a ressusité, 143.

${ }_{47}$ Zob. G. Stemberger, Der Leib der Auferstehung, por. wyżej przypis 35.

48 Ek 24, 13-35. 41-43; Dz 1, 4; 10, 41. Por. J 21, 12-13; Mk 16, 14. Przykladem pewnej ,reinterpretacji" semickiej idei ,cielesności” ciała zmartwychwstałego przy pomocy hellenistycznej idei ,spirytualności” jest argumentacja w 1 Kor 15, 35-49.

49 Zob. J. Schmitt, art. cyt., 230-233. 
pologiczno-kultura l ne go. Chodzi o sposób myślenia właściwy świadkom wydarzenia paschalnego i autorom opowiadań o tych wydarzeniach. Słusznie zwraca na to uwage konstytucja Dei Verbum (n. 12): „By zdobyć właściwe zrozumienie tego, co święty autor chciał na piśmie wyrazić, trzeba zwrócić należytą uwagę tak na owe zwyczaje, naturalne sposoby myślenia, mówienia i opowiadania, przyjęte w czasach hagiografa, jak i na sposoby, które zwykło się było stosować w owej epoce przy wzajemnym obcowaniu ludzi z sobą." W argumentacji za obiektywnym sensem wydarzeń historii zbawienia nie możemy polegać tylko na rodzajach literackich oraz na pracy redakcyjnej hagiografów (Redaktionsgeschichte) ${ }^{\mathbf{5 0}}$. Musimy się przede wszystkim odwołać do common sense ówczesnych ludzi, do właściwych im sposobów przedstawiania faktów obiektywnych. Byłoby nonsensem utrzymywać, iż ówcześni autorzy przedstawili tylko subiektywne odczucia zaistniałych faktów ${ }^{51}$.

Obiektywny sens zmartwychwstania Jezusa jest metodologicznie uwiarygodniony i uzasadniony warunkami historycznymi, religijnymi i kulturalnymi chrześcijańskiej gminy w Jerozolimie. Naoczni świadkowie zespołu faktów, jak pusty grób, obcujący z nimi żywy Chrystus, przekazali nam swoją wiarę w obiektywny sens zmartwychwstania, wiarẹ opartą na doświadczeniu Zmartwychwstałego, doświadczeniu paschalnym - a nie struktury językowe, w których wyraziliby swoje nadzieje i tęsknoty. Obiektywnie sens zmartwychwstania jest osiągalny nie tylko dla Apostołów, ale i dla nas, którzy przyjmujemy naukę apostolską na tym polega owa dynamika przekazu wyrażona przez św. Pawła w 1 Kor 15, 3: parédôka - parélabon. Dlatego niebezpieczne są ewolucje tych autorów, którzy nie chcą przyznać pełnej obiektywności zmartwychwstaniu Jezusa, chociaż zakładają fakt historyczny ${ }^{52}$. Odmawianie peł-

50 Coraz to częściej zwraca się uwagę na niewystarczalność z jednej strony biblijnej genologii, a z drugiej - metody historii redakcji. G e n o logi a bi blij n a powstała w oparciu o analizy europejskich form literackich i nowożytnych sposobów ujmowania tworzywa literackiego. Historia form literackich, która powstała na gruncie literaturoznawstwa XIX-wiecznego, była z powodzeniem stosowana przez E. Nordena do literatury antycznej, zanim H. Gunkel nie wprowadził jej na teren biblijny. Zob. H.-J. Kraus, Geschichte der historisch-kritischen Erforschung des Alten Testoments, Neukirchen ${ }^{2} 1969,344$. Redaktionsgeschichtliche Methode nie może się zasklepiać w podziale małych, niejednokrotnie niezależnych form literackich, lecz musi pozostać otwarta na kontaki z rzeczywistością, w której owe formy powstawały. Por. E. Güttgemanns, Offene Fragen zur Formgeschichte des Evangeliums. Eine methodologische Skizze der Grundlagenproblematik der Form- und Redaktionsgeschichte (Beiträge zur evang. Theologie, 54), München 1970. - G. Schille, Osterglaube (Aufsätze und Vorträge zur Theologie und Religionswissenschaft, 56), Berlin 1972, zob. zwłaszcza Methodische Folgerungen.

51 Por. R. C. Denton (ed.), The Idea of History in the Ancient Near Eeast, Yale University Press, New Haven - London 1966.

$52 \mathrm{X}$. Léon-Dufour tak to formułuje $\mathrm{w}$ sposób nieco zagadkowy: „L'expérience s pirituelle des disciples, non purement s ubjective, répétée, partagée entre eux, été communiquée, par la médiation du langage ambiant et de la tradition religieuse, en particulier à l'aide de leur foi en la résurrection collective à la fin des temps." (podkreślenia moje, J. Ch.). Résurrection de Jésus et message pascal, Paris 
nej obiektywności faktowi zmartwychwstania Jezusa oznacza popadnięcie w niebezpieczeństwo rozłamu między historią a wiarą, prowadzi do uprzywilejowania jednego typu doświadczenia na niekorzyść innych typów, daje prawo pierwszeństwa bez uzasadnienia znaczeniu przed faktem, pojęciu przed podmiotem.

Jakie postulaty trzeba wysunąć pod adresem hermeneutyki zmartwychwstania Chrystusa?

3.1 Winna to być hermeneutyka wy darzenia w mowie, a nie - jak chciała hermeneutyka Schleiermachera i Diltheya, romantyczna i psychologizująca - wydarzenia słownego ${ }^{53}$. Innymi słowy - winna to być hermeneutyka przekazu o doświadczeniu faktu zmartwychwstania, a nie kodu o znaczeniu zmartwychwstania. Hermeneutyka taka dociera do przeżycia faktu, do specyficznego doświadczenia religijnego, jakim było niewątpliwie doświadczenie paschalne.

3.2 Hermeneutyka zmartwychwstania Chrystusa winna być integ ralna i integrująca, to znaczy ustawiająca krzyż i zmartwychwstanie na płaszczyźnie faktycznie $\mathrm{z}$ sobą związanych wydarzeń zbawienia. Jeśli śmierć na krzyżu była akceptacją ze strony Jezusa Chrystusa planu zbawczego zleconego $\mathrm{Mu}$ przez Ojca, to zmartwychwstanie jest odpowiedzią Ojca na wierność Syna ${ }^{54}$. W ten sposób śmierć i zmartwychwstanie Chrystusa nie staną się symbolami, lecz rzeczywistościami życia Jezusa Mesjasza.

3.3 Wreszcie hermeneutyka zmartwychwstania Jezusa powinna być wieloaspektowa. Chrystus Zmartwychwstały jest Panem wszechświata, ale jest także moim Panem ${ }^{55}$. Zmartwychwstanie Chrystusa jest tak ważne dla całego świata (aspekt k o s mi c z-

1971, 275. Nic tedy dziwnego, że wokół, skąd inąd doskonałej, książki Léon-Dufoura powstała kontrowersja, o czym zob. bliżej K. Sokołowski, Z dyskusji nad zmartwychwstaniem Jezusa, „Ruch Bibl. i Lit.”, 25 (1972) 219-229. - P. Grelot, Croire au Christ ressuscité, „Etudes”, (juillet 1972) 119-141. C. Duquoc znów w swej chrystologii indukcyjnej uważa zmartwychwstanie Jezusa za wydarzenie półobiektywne: obiektywne jest tylko dla Chrystusa, dla nas - nie. Zob. uwagi krytyczne, jakie sformułował w swej recenzji B. Mondin w „L'Osservatore Romano”, 26-27 marzo 1973, 5 i 7.

$53 \mathrm{Na}$ konieczność hermeneutyki wydarzenia w mowie zwraca ostatnio uwage P. Ricoeur, Evénement et sens dans le discours, w: Paul Ricoeur ou la liberté selon l'esperance. Présentation, choix de textes, biographie, bibliographie, par M. Philibert, Paris 1971, 177-187. [Tłum. polskie: Wydarzenie i sens w mowie, ,Teksty”, n. 6 (1972) 103-118]. Zob. również J. Chmiel, Problem hermeneutyki Nowego Testamentu, w: W spótczesna biblistyka polska 1945-1970. Praca zbiorowa pod red. J. Eacha i M. Wolniewicza, Warszawa $1972,159-171$.

54 Podkreśla to C. Duquoc w swojej chrystologii indukcyjnej. Zob. wyżej przy pis 52 .

55 Zob. X. Léon-Dufour, Résurrection de Jésus et message pascal, 305-309. 
ny zmartwychwstania) jak i dla mnie osobiście (aspekt egzystencjalny zmartwychwstania) ${ }^{56}$. Tak to chyba pojmował Jan Teolog: „Jam jest Pierwszy i Ostatni, i Żyjący.

Byłem umarły, a oto jestem żyjący na wieki wieków i mam klucze śmierci i otchłani." (Ap 1, 17-18).

56 Najnowszy zarys teologii zmartwychwstania dał wielokrotnie już wspomniany B. Rigaux, Dieu l'a ressuscité. Exégèse et théologie biblique (Studii Biblici Franciscani Analecta, 4), Gembloux 1973. Zob. zwłaszcza cz. III. Dans la mouvance du Ressuscité. 